\title{
Miranda
}

Revue pluridisciplinaire du monde anglophone /

Multidisciplinary peer-reviewed journal on the English-

speaking world

23 | 2021

Modernist Exceptions

\section{Can Anonymous be the exception? Modernist anonymity and the challenges of literary exceptionalism}

\section{Anne Reynes-Delobel}

\section{OpenEdition}

\section{Journals}

Electronic version

URL: https://journals.openedition.org/miranda/42260

DOI: $10.4000 /$ miranda.42260

ISSN: 2108-6559

\section{Publisher}

Université Toulouse - Jean Jaurès

\section{Electronic reference}

Anne Reynes-Delobel, "Can Anonymous be the exception? Modernist anonymity and the challenges of literary exceptionalism", Miranda [Online], 23 | 2021, Online since 12 October 2021, connection on 29 November 2021. URL: http://journals.openedition.org/miranda/42260 ; DOI: https://doi.org/10.4000/ miranda. 42260

This text was automatically generated on 29 November 2021.

\section{cc)}

Miranda is licensed under a Creative Commons Attribution-NonCommercial-NoDerivatives 4.0

International License. 


\title{
Can Anonymous be the exception? Modernist anonymity and the challenges of literary exceptionalism
}

\author{
Anne Reynes-Delobel
}

In view of the efforts deployed throughout the 1920s by the Paris-based American writers, editors, and publishers to articulate modern writing as exceptional to, rather than constitutive of, literary production, approaching modernist "exceptionalism" from the perspective of authorial anonymity may at first seem counterintuitive. Indeed, despite their often vexed relationship to a larger, "mainstream" public, the set of strategies of market economics they used or devised to secure trade channels for new writing-such as books series or collections, limited deluxe editions or cheap reprints-were all placed under what Herbert Tucker calls "the propertied regime of the proper name" (Tucker iv). A letter addressed by Ezra Pound to William Carlos Williams on 18 February 1931 (Witemeyer 107) is a case in point. In it, Pound described to "Deer Bull" one of his indefatigable attempts to break the stronghold of commercial publication and "get stuff into print." His mode of "AXSHUN" consisted in asking three small magazine editors in the United States to each take charge of the printing and shipping costs of 150 copies of cheap books to be printed in Europe, which would keep sale price low enough to ensure that "they'd sell and not clog storage rooms". Any sale would go to paying authors ("the bloody unfed"). To fulfill this goal, each participant was to furnish a list of authors "considered worthy to be printed", and the letter included the listed proposals Pound made for that purpose. After asking Williams for his own suggestions and advising him not to "yawp" about their venture to "people who [couldn't] act", he went on mentioning "Lowenfels Carrefour Edtns", telling his friend that they "wd. be glad to have [him] anonymous if [he] could stand for that". This intriguing two-minded allusion to the small press Walter Lowenfels and Michael Fraenkel had founded in Paris the year before as a vehicle for the movement for anonymity ${ }^{1}$ indicates that Pound was both ready to support the efforts of Anonymous 
and unwilling to endorse the kind of radical relinquishing of authorship and control it advocated for.

Pound's guarded response recaptures the tension between modernists' claims for literary exceptionality-and their need to carry off the myth of their own exceptionalism-and their reliance on impersonality as a way to escape from the personal into communicable significance. Even a cursory glance at Anonymous. The Need for Anonymity, the-necessarily unsigned-manifesto published by Carrefour Editions, reveals that its authors were intent on reaching the same ends as those pursued by Pound and the other editors and publishers of the expatriate literary community, albeit with different means. Describing Anonymous as a "homogenous phalanx" and a "common trust" set on creating their "own market-the Anonymous audience" (Anonymous 19) so as to be "continually the unique, the individual, fresh significance without which the audience-the world-is lost" (13), the declaration clearly foregrounded the ethos of the movement in the "creative impulse" (10) of "the 'unusual' artist and 'unusual' art" (22), and the "need for difference and differentiation" in a world dominated by a "mass of insignificance and replica operating as 'art"' (22). Yet, owing to the fact that "the competitive struggles for names in art" (16) and the correlated pressure on the artist "to produce what he [could] sell rather than what he [could] produce" (12) made it no longer possible to privilege the power of the exceptional and the new, to remain anonymous was the only way to both preserve the "sanctity" of individual creation, and merge into the anonymity of society in general to "react vitally on it, not as one outside of it" (16). In other words, Anonymous purported, in true avant-gardist spirit, to recapture the unity of art and life by bringing individual, perforce egotistic, artistic creation to bear upon the world and, simultaneously, by enabling the anonymous audience to take part in a form of "authorization" of the artwork.

3 If we agree that, as a centuries-long cultural practice, literary anonymity is not an exception, but the rule (Tucker I; Griffith 891), then it is interesting to ask what it was that led the authors of Anonymous to make it the vehicle of modernist exceptionality. Their rejection of authorial identification or exposure might partly have derived from the idea that anonymity was vanishing in their own time-a notion framed within the debate on mechanical and industrial civilization, and its impact on cultural modernization, that was largely disseminated by newspapers and magazines on both sides of the Atlantic. It also reflected anonymity's and impersonality's discursive entanglements within and across modernist circles, and more specifically their connections with modernist negotiations with socioeconomic order and phenomenological encounters with the world. As a movement claiming that "organized impersonality" (27) could act as a corrective to social and spiritual disintegration, Anonymous demonstrated an attempt to conjoin the two paradigms of impersonalitycultural and aesthetics-into a political project described in the manifesto as "an active effort to shape the destiny of the world and to contribute to world unity" (20).

From a strict theoretical perspective, it can of course be argued that the conflation of "anonymity" and "impersonality" is not as self-evident as Anonymous would have us believe. The confusion may have partly to do with the literary context of the 1920s, a time when, as Anne Ferry had noted, critical discussions about impersonal and objective gave the noun anonymity a "looser meaning-almost as an antonym for personality[that] smoothed the way for its use elsewhere for written pieces in fact signed by the 
author but exhibiting the impersonality associated with anonymity by removing the poet, so to speak, from the poem" (Ferry 198). One place where we can watch this extension happening is the Anonymous manifesto which, though it still uses anonymity to refer to writings that are literally unsigned, also makes it a crucial stylistic instrument to the pull towards the social and the aspiration for community, as well as the search for individuation of voice without unitary subjectivity, and, more particularly, to T.S. Eliot's vision that "the pastness of the past" and also its presence (Eliot 14) define the space of poetry, the individual talent, and the subjectivity of narrative, emerging in the effort toward intelligible unity.

The purpose of this article is to examine how Anonymous's balancing of diverse cultural, political and aesthetic drives can advance our understanding of modernist exceptionalism as a heterogeneous and malleable cultural construct. By contextualizing Lowenfels and Fraenkel's ideal of anonymous publication within the contemporary debate over anonymity, it reassesses its political and aesthetic stance. Though Lowenfels and Fraenkel's project was difficult to reconcile with the reality of the book trade-as Pound had rightly guessed-yet it encouraged a number of experiments which reflected a collective concern with the formalization of a new American poetic idiom. The article discusses some of these writings so as to demonstrate that, for their authors, to claim, disclaim or reclaim authorship was a way to reassert cultural and social authority within the culture of the market place. By investigating the connection of these experiments with the late 1920s technomodernist "revolution of the word", it also emphasizes the challenge these writers faced as they tried to avoid the pitfalls of cultural exceptionality.

\section{Anonymous in context}

6 At the time when Anonymous published its manifesto, which probably coincided with the establishment of Carrefour Editions at Fraenkel's home, 18 Villa Seurat, in 1930, the reasons for anonymous publication were a topic of interest and debate across a large segment of the periodical press. As Anne Ferry has noted, the noun "anonymity" began to crop up in popular journals in the last two decades of the $19^{\text {th }}$ century and, by the 1920s, it was introduced in critical discussions about the significance and qualities of literature, and in particular, poetry (Ferry 197-98). In the United States, one of the defining moments in this debate was a contribution to the May 1926 issue of The American Mercury by Henry Seidel Canby, a Yale professor and editor of The Saturday Review of Literature, and the editorial chair of the newly-founded Book of the Month Club. As its title eloquently suggests, "Anon. is Dead" was devised as an obituary for a form of publication of undeclared authorship which in the $18^{\text {th }}$ and $19^{\text {th }}$ centuries was, as Robert J. Griffin has pointed out, as much a norm as signed authorship (Griffin 879-80). Taking stock of its demise, Canby described it as an "old form of address" whose "still formalities" and "remote third person" had "no value in a democracy" (Canby 1926, 84). Yet, the point he wanted to address was the socially harmful effects of modern urban anonymity and the ethical implications of a corresponding "increase in egomania" (79). In a depiction that strikingly resembles the present-day networked society of the information age in which anyone can be manufactured into a standardized celebrity commodity, he deplored the "panicky, almost hysterical attempt 
to escape from the deadly anonymity of modern life" (80), and called for more "responsibility in the personal" (84).

7 If Lowenfels' and Fraenkel's attack against the mechanical processes-such as "comprehension and imitation"-which the material and social world imposes up on the individual (Anonymous 21-22) echoed Canby's argument against "the passion for nonanonymity" (Canby 83), it even more strongly resonated with an article by E. M. Forster, "Anonymity: An Enquiry," which was simultaneously issued in November 1925 in the British literary journal, The Calendar of Modern Letters and in The Atlantic Monthly. Forster's essay addressed the question of anonymity from a strictly literary perspective to denounce the importance given to the author's personality or biography to the detriment of "the creative impulse" (Forster 152):

And here is the point I would support: that all literature tends towards a condition of anonymity, and that, so far as words are creative, a signature merely distracts us from their true significance [...].

What is so wonderful about great literature is that it transforms the man who reads it towards the condition of the man who wrote, and brings to birth in us also the creative impulse. Lost in the beauty where he was lost, we find more than we ever threw away, we reach what seems to be our spiritual home, and remember that it was not the speaker who was in the beginning but the Word. $(150,152)$

What Forster describes as a movement outward towards creation, Anonymous manifesto also describes as a movement, "from within, outward, to attack the problem at the core, to recapture the unity of man and the world by an attitude toward creation" (Anonymous 10). In both cases, anonymity is the condition of poetry. Forster further argued that to want to know about the author's name and personality was not to read but merely "to study," an activity he relegated to "a serious form of gossip" (Forster 153).

9 This idea brings to mind the experiment the Cambridge critic and professor I. A. Richards devised during the 1920s to encourage close reading among his students with a view to avoiding the pitfalls of preconceived or received beliefs about a text. Each week, Richards gave his students anonymous poems to read and comment on in writing. The analysis of these "protocols" formed the core of Practical Criticism. A Study of Literary Judgment (1929), which contributed to the foundations of the New Criticism. Though Richards was keenly intent on increasing readers' analytic powers by grounding reception in the moment of communication between reader and poem, yet the fact, as Aaron Jaffe has demonstrated, that his method used temporary anonymity as a means to recursively attribute authorship through the authoritative process of interpretation made it a decisive component in the canonization of modernism in the academy (Jaffe 83-87). From this point of view, it starkly diverged from the objectives of Anonymous, which considered originality and singularity not as an end in themselves, but rather as a means to an end-the creation of a "neighborhood" or "sympathy" which "makes it possible for society to absorb and become its own contemporary spirit" (Anonymous 16-17).

10 As this quote stresses, emphasis on the "unusualness" of "the contemporary" was a central tenet of Anonymous, to the apparent exclusion of tradition and the past. Not surprisingly, the last sentence of the manifesto declares "It is not good facing a 1940 world with an 1830 soul" (25). In this sense, Anonymous also appears to diverge from Richards' method of practical criticism, which was closely connected with the defense of T. S. Eliot at Cambridge and indebted to his theory of impersonality. However, 
despite some appearances to the contrary, Anonymous was not beyond the long shadow cast by Eliot's ideas on tradition and originality, and of his doctrine of depersonalization and artistic self-effacement as a response to cultural crisis. To clarify this point, it is necessary to probe into the notion of "disintegration" that sustained the movement and inspired the form of poetic practice that derived from it. In the eyes of its proponents, disintegration was not only the condition of the modern man, resulting from the mechanical forces and the ideological transformations that shaped modern life, but it was also, and even more importantly, a "field of force" (21) that the artist had to create in order to bring his work in step with modernity, and thus merge with the spirit of the time. All these ideas owed much to the apocalyptic philosophies of culture that infused Fraenkel's thinking, in particular those developed by Spengler and Keyserling, and to Nietzsche's and Lawrence's dualistic metaphysics based on the polarity of life-giving and life-denying forces.

11 Fraenkel's conception of disintegration as a mental and creative attitude was undoubtedly at the source of Anonymous, whose project stemmed from his meeting with exile poet Walter Lowenfels in 1928, and their decision to join forces to launch a small press that published books anonymously in keeping with the author's manifesto. Anonymous. The Need for Anonymity was the first book published under the Carrefour imprint in 1930. The same year, Carrefour also published anonymously Fraenkel's first book Werther's Younger Brother, which formulated his ideas about death, and Lowenfels' USA with Music, a play inspired by the 1922 Herrin Massacre. Somewhat ironically, this publishing venture came to an abrupt end in 1932, when Lowenfels sued George S. Kaufman and George Gershwin for plagiarizing his work to make their 1931 Broadway musical, of Thee I Sing. However, if the practice of anonymous publication was shortlived, the ideas that sustained it proved to have a lasting effect on the group of writers who assembled at Villa Seurat to discuss anonymity in the first years of the 1930s, and continued to discuss the topic in their correspondence throughout the decade and beyond.

12 Henry Miller, who met Lowenfels and Fraenkel in the summer of 1931, shortly before he immersed himself in the writing of the first draft of Tropic of Cancer, was durably inspired by Anonymous. In "Creative Death", an essay issued in the London magazine Purpose in 1938, he rearticulates the idea that the artist's "capacity for life" is proportional to his willingness to escape life and "play the monstrous role of living and dying innumerable times" so as "to convert the obsession of individuality into a common collective ideology" (Miller 1938, 76). These words echo Anonymous declaration which states that "every poet has the continual opportunity of dying, young. He dies continually as an artist to allow himself to live more than ever as an individual" (Anonymous 17). In the concluding lines of his essay, Miller sheds more light on the singularity of the artist driven by "creative death" in regard to cultural tradition:

This is the real meaning to the Master-Exemplar, of the great religious figures who have dominated human life from the beginning. At their further peak of blossoming they have but emphasized their common humanity, their innate, rooted, inescapable humanness. Their isolation, in the heavens of thought, is what brings about their death. (Miller 1938, 78)

13 This statement conveys the idea that "the creative will continually seek to incorporate and consume itself into the living stream of collective life and consciousness." But when this process is interrupted and the creative impulse is turned into an abstract 
principle or an eternal truth, then the artist can no longer "react vitally on the world" and "real death" settles in. In other words, as in the theory of the impersonal aesthetic famously spelled out by Eliot in "Tradition and the Individual Talent", the progress of an artist is a continual self-sacrifice, but this process does not seem to entail the form of mutual alteration of past and present that characterizes Eliot's idea of tradition. Instead, the emergence of tradition proves deadly to the artistic process, as it drives a wedge between man and world. Anonymous recognizes that the artist's will "to integrate disintegration to the very bone" may deter the audience from engaging with the work and drive them to retreat into the illusion of the "unified past of an earlier age", but this only tends to show that "they are not alive in their own time, but are ghostly" (24).

On closer inspection, however, it appears that Anonymous was perhaps not so much eager to "liquidate the past, and come into fresh ground", as Fraenkel noted in Werther's Younger Brother (Fraenkel 1930, 52), as to make the past the ground for a new awareness of what he later described as "a process of inner-transmutation, conversion, by which alone man can lift himself out of the white-heart rot of death into a new livingness" (Fraenkel 1939, 50). In Fraenkel's eyes, the "becoming ghostly" of the world could be traced back to the disconnection of the individual self from his own life's rootedness originating in the "Hamlet theme" or what Miller calls the "death of the procreative body" (Miller 1935, np) that was at the core of his correspondence with Fraenkel. Since 1930, Fraenkel, Miller and Alfred Perlès had been planning a joint publication called Three Essays in Weather Counterpoint containing their respective writings about the spiritual death of social man in modern society, and its devastating effects on both the artist's and the world's creative consciousness. ${ }^{2}$ As Michael Harris explains, the idea was shelved and the three writers settled instead for publication in the form of an exchange of letters called the "Hamlet correspondence" and published in two volumes by Carrefour in 1939 and $1941^{3}$.

The "Hamlet theme" finds its roots in D. H. Lawrence's chapter on Hamlet in Twilight in Italy which was a major source of inspiration for Fraenkel's doctrine of anonymity. Indeed, Lawrence's understanding of Hamlet as the embodiment of a negative trend in Western sensibility leading to "the convulsed reaction of the mind from the flesh, of the spirit from the self" (Lawrence 2002, 144) supported Fraenkel's own view of modern self-annihilation, and was a frequent topic of discussion at Villa Seurat, as well as the starting point for a sustained exchange of letters with Miller. A detour by way of a letter that Miller addressed in 1935 to Perlès clarifies the issues that were at stake in Fraenkel's and Miller's respective attempts to create a radically new form of anonymous aesthetics. In this letter, Miller explicates the importance of the "Hamlet theme" in relation to his "Lawrence book" and to Fraenkel's conception of "creative death". In Lawrence's eyes, Miller writes, Hamlet's decision that "the Self in its supremacy, Father and King" must die (Lawrence 2002, 145) signals a radical departure from an earlier world-exemplified by Rabelais-when "the world [was] the body [and] the importance of the personal was almost nil" (Miller 1935, np). For Miller himself, Hamlet's self-nauseating isolation symbolizes "the death of the procreative body" and the corresponding supremacy of the personal. He goes on explaining to Perlès that the absence of "corpus" in modern, mechanized society and the transformation of life into "an abstract point-space geometry of dynamics" is the continuation of a long process of cultural disintegration that started when "Rabelais and Shakespeare went out with the body of the world." Both Fraenkel and Miller shared Lawrence's conclusion that the 
question Hamlet had to settle remained crucial, for it pointed at the fecundating power of the process of dying. As Lawrence wrote: "To be or not to be was the question for Hamlet to settle [...] It is a question of knowing how to be, and how not to be, for we must fulfill both. [Modern man] has still to let go, to know what not-being is, before he can be" (Lawrence 2002, 148). Miller echoed Lawrence's injunction by stating that it was the modern artist's duty to establish "a new relationship to the world, by seizing anew the sense of death on which all art is funded and reacting creatively to it" (Miller 1959, 205). Lawrence's criticism on Hamlet provided Anonymous with a site of confrontation with literary tradition and a breeding ground for their own reconfigurations of the process of "creative dying". As a means to counter the becoming ghostly of the "supreme self" and concurrent rise of the "personal" (what Lawrence calls "not being," or the creed of "paltry selfishness"), anonymity proponed a form of exceptionality that precluded any facile understanding of the categories of the "personal" or the "impersonal," instead opening them to critical scrutiny and creative invention.

\section{"Creative Death": ruling out the exception}

Soon after Fraenkel and Lowenfels met in Paris, in 1929, they decided to run Carrefour and settled for the elegy as the vehicle for Anonymous publication. The idea probably owed much to Lowenfels who was already a published poet in the United States ${ }^{5}$, and whose poem, Apollinaire. An Elegy, was contracted by Nancy Cunard to be published in 1930 as the first book in the Second Hours Press series. ${ }^{6}$ The book, which epitomizes Cunard's experiment in printing and publishing, combines the tradition of fine printing and modern, avant-garde poetry and art. The lines between quotation marks at the beginning of the poem, "The angels loop the loop / around the poet in the flying suit" introduce the reader into a chant in which "Apollinaire" is a referent of Anonymous's doctrine of "creative death". The quote points to the subtext, Apollinaire's own poem "Zone" (1913), which partly resurfaces in the poem as a site of transient encounters with images continually re-engendering "Apollinaire" in new associations and meanings. The angels moving in loops around the poet/aviator/Christ ("Les anges voltigent autour du joli voltigeur," Apollinaire 48) are a paradoxical "conjunction" (Lowenfels 1930, 11), an impossibly objectifiable "objective correlative" that transmute "Apollinaire" from "singing grammar" (13) to a Keatsian Apollo stranded in the impersonal, tawdry modern city ("and Apollo drives the horses of the sun / down the street to collect loud garbage", 26-27), to the multitude of emigrants "at the Gare St. Lazare" (30-32), who are also kin to the numberless anonymous immigrants caught in the violent processes of nation-building, such as the victims of the East St. Louis Riots in 1917:

there's

the cold comfort of objective immortality;

statistics rule a million millions

the oppression of whose certain numbers

leaves their dying epic an almanac

and no sadder than the census of East St. Louis. (Lowenfels 1930, 35-40)

As if to counteract this inexorable destitution, the persona, voicing a communitarian impulse, runs up and down the pronominal scale, going from one pronominal mask to the next, and appropriating all of them without being reduced to any one of them: 


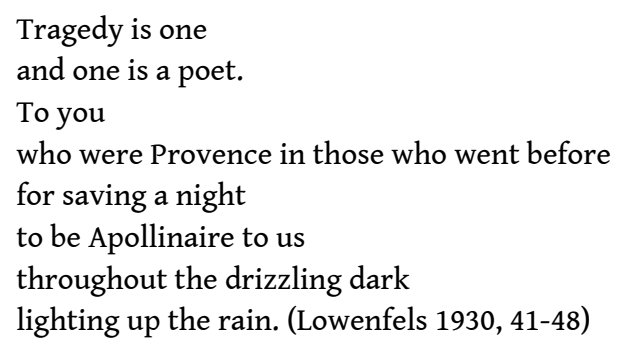

$$
\text { with }
$$
cosmos and body forth into a new life" (Fraenkel 1939, 49), contradicted Hiew that Lawrence was comparable in stature to Jakob Boehme or William Blake. To Fraenkel, Lawrence had no interest in universal ideas or values. His "otherness" lied in his "immediate, personal significance" (12), which made his work a "process," or, to use a phrase from the Anonymous manifesto, "an unfinished symphony" (Anonymous 22). From that point of view, Fraenkel argued, to enroll Lawrence among the apotheosized geniuses of the past ran counter to his aesthetic of anonymity. However, in the face of the transatlantic controversy that was raised by Lawrence's death on the second day of March 1930, to avoid enrolling him in the pantheon of the geniuses of the present proved to be more difficult. This idea had also been voiced by Fraenkel in The Otherness of D. H. Lawrence (1939), in
which he demonstrated that Lawrencian monism, or the individual will to "reconnect To many within the American literary community, Lawrence epitomized the struggle against a form of cultural domination which was congenial to their own quest for cultural regeneration and self-determination. As Dennis Jackson has noted, news of Lawrence's untimely death elicited more sympathetic response in American journals and newspapers than it did in those published in London (Jackson 54). Among those who saluted Lawrence's vitalism and sexual energy was Sherwood Anderson who wrote: "You feel the man's flesh in his words, the nerves alive, the man smelling, tasting, 
seeing" (Anderson 22). Others, like Henry Canby, envisaged Lawrence from the perspective of his anti-Puritanical crusade, as "the fanatic who burst through the gate of Victorian reserve" (Canby 1937, 817)7. Within transatlantic modernist circles, Lawrence was seen as a kindred spirit of such explorers of the American experience and dark psyche as Poe, whom Lawrence described in his Studies of Classic American Literature (1923) as "an adventurer into vaults and cellars and horrible underground passages of the human soul", who "sounded the horror and the warning of his own doom" (Lawrence 2003, 80). Poe's need to consummate himself into the nation's state of consciousness made his writings the reflection of a tradition of violence that Lawrence asked to be rediscovered through the encounter with the spirit of the place: "Americans ... must catch the pulse of the life which Cortes and Columbus murdered. There lies the real continuity not between Europe and the new states, but between the murdered Red America and the seething White America" (Lawrence 2003, 384).

Lawrence's call was answered by William Carlos Williams in In the American Grain (1925) which revisited the history of the discovery of the American continent from a hermeneutic perspective by probing into different modalities of encounter with the local so as to raise the question of cultural belonging. In Williams's chronicle, Poe stands on the side of those, such as Sébastien Rasle or Daniel Boone, who are willing to "touch" America and come into contact with the specificities of the American experience, and those, such as the Puritans, de Soto or Cortez who, as Lawrence wrote in his review of Williams's book, prefer "recoiling into individual smallness and insentience, and gutting the great continent in frenzies of mean fear. It is the Puritan way. The other is by touch; touch America as she is; dare to touch her! And this is the heroic way" (Doyle 91). Williams' "localist" project of renewed spiritual and cultural contact with his homeland had a great deal of influence on the transatlantic Americanist avant-gardes that attempted to devolve Anglocentric authority by reinstating other hegemonies.

In such a context, it was perhaps inevitable that Williams and Lowenfels would seize upon the occasion of Lawrence's death to vent their impatience with the American audience's indifference or resistance to new work. In "An Elegy for D. H. Lawrence: Died 2 March 1930" (1932), Williams indicts England for having forced Lawrence into embittered exile:

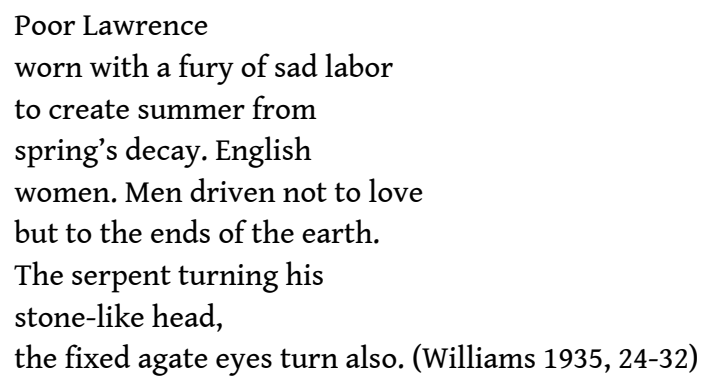

In the second stanza, the use of the third person establishes a sort of anonymous kinship between the poet and Lawrence (who never answered a letter Williams wrote to him):

Once he received a letter-

he never answered it- (Williams 1935, 9-10) 
relational engagement with the non-relational liberates the poem from pathos; as the perception of Lawrence becomes a chaotic mental train of images and references loosely borrowed from his works, Lawrence's exile is realized as unfettered mobility:

Remember, now, Lawrence dead.

Blue squills in bloom-to

the scorched aridity of

the Mexican plateau. Or baked

public squares in the cities of

Mediterranean islands

where one waits for busses and

boats come slowly along the water

arriving. (Williams 1935, 61-69)

The elegy's translocational energy figures the cultural shaping of Anonymous creative death. ${ }^{8}$ It sustains the search for a poetics that traverses the boundaries of nation and culture, creating an imagined transnational community whose shared sense of location is based, paradoxically, on a form of organized dislocation.

Lowenfels' "Elegy in the Manner of a Requiem in Memory of D. H. Lawrence", which was published anonymously by Carrefour in April 1932, is also constructed in the form of a collage of images loosely related to Lawrence's life and work, but its liberal use of pathetic fallacy gives it a more distinctly elegiac tone:

He moves among the miles

like Switzerland among the blue bells

But the edelweiss we picked

among the leaves.

It is turned to day by day.

It yellows slowly. It spreads its wings.

It folds and unfolds. (Lowenfels 1932, 11)

While Williams' vignettes engage the reader into the commonality of contact with the anonymous "things" in the world, Lowenfels' tries to convey the auditory experience of communal mourning: ${ }^{9}$

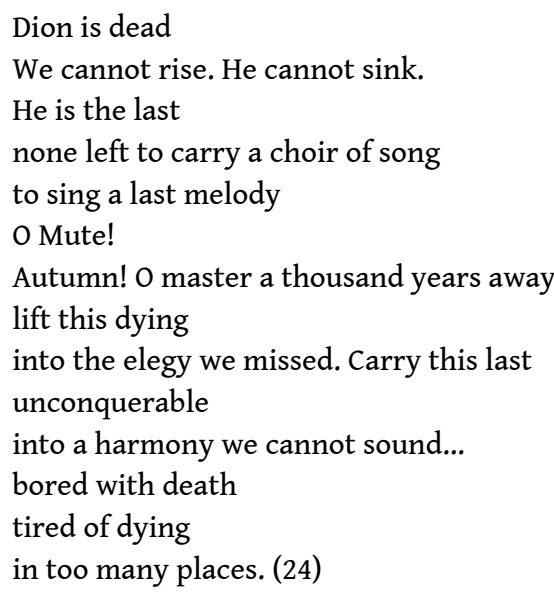

In the aural economy of the elegy, Lawrence's dying is paradoxically dedicated to the poem's radical other ("O Mute!") so as to operate a movement toward infinite transcendence that cannot be an object of knowledge ("a harmony we cannot sound...”). By grounding the text in the strangeness of anonymity, the poet invites the audience to partake, simultaneously, into an attitude towards the unknown which authorizes a form of relation irreducible to appropriation or domestication. This kind of process points, as Mark Robson argues, to an ethics of anonymity whereby "the 
strangeness of textual anonymity is recognized without being immediately neutralized" (Robson 363). From this ethical perspective, it is possible to envisage Williams' and Lowenfels' elegies to Lawrence as an attempt to advance the project of cultural regeneration of the transatlantic avant-gardes while avoiding to essentialize his alterity as "exceptional".

Another aspect of Lowenfels' elegy tends to support this argument. Part V of the poem, "Among the Revelations", describes Lawrence's self-sacrifice as organic disintegration:

Saprini Sarcophagi

The master of ghouls

All workers in putrefaction

The white bark of them egg-laying

A white manna of the sea. (29)

In accordance with the spirit of Anonymous, this "revelation" seeks to recover what Fraenkel called in his 1939 essay on Lawrence "death into life" or "the organic process of transformation whereby only the body sense can be recovered: a process whereby the very material of decay itself becomes a fresh source of life [...] the process of dying, in a word, [that] lifts the whole question from the realm of theory into living fact" (Fraenkel 1939, 54-55). In that regard, however, Anonymous interest in the creative potentialities of the organic body for the rejuvenation of the poetic idiom was not an isolated phenomenon, but it overlapped with other experiments carried out by the expatriate avant-garde.

\section{Reading Anonymous with the machine: exception or the rule?}

At the time when the Anonymous group was engrossed in the reading and discussion of Lawrence's work at Villa Seurat, and Anaïs Nin was developing her own understanding of Lawrence's approach to speaking from the body ${ }^{10}$, the Paris-based literary journal transition was also the site of experiments grounded into a questioning of the relationship between the physiological body and artistic creation. While these experiments stemmed from the work and interests of each individual contributor, for the magazine's editor, Eugene Jolas, they were also a means to organize a collective response to French Surrealism so as to differentiate transition from Breton's movement while broadening its possibilities. This project can be described, very schematically, as an attempt to synthesize a Jungian approach to the creative process as an impersonal activation of the primordial experiences resting in the collective unconscious and a word revolution calling for the invention of new myths for the modern machine age. The "Proclamation" in the Revolution of the Word double issue of June 1929 cast this project into a rhetoric of novelty and singularity. The often-quoted manifesto announced the advent of a new tradition of the "new" by calling for the dismantling of syntax, the disintegration of pre-existing word, and the fashioning of a new vocabulary meant to counteract the pervasive ideologies of a "rotting civilization" (transition June 1929, 13).

An intriguing poem written in 1931 by Kay Boyle, one of the regular contributors to the magazine, can be seen as a sort of prototype for transition's aesthetic agenda. Dedicated to Boyle's literary agent, "A Landscape for Wyn Henderson" is an elegiac lament mourning the death of an unnamed lover. It was in all likelihood written in memory of 
Boyle's companion and the father of her first child, the poet and editor Ernest Walsh, to whom she dedicated a series of poems after his premature death in 1926. However, the anonymous dead might as well have been Lawrence-whose death was the inspiration, also in 1931, of an impressive short story, "Rest Cure", a thinly-veiled reference to the final days of Lawrence's life in the south of France-or perhaps Harry Crosby, Black Sun Press editor, who committed suicide in New York, at the end of 1929. In any case, the suppression of the subject's identity redirects attention to an intensely self-conscious, anti-elegiac refusal to find solace and restitution in the traditional patterns of commemoration in culture. Instead, the disjointed syntax and disjunctive associations evolve into an impersonal, indirect, and open style that eschews punctuation:

Were made were not for lament for sore melodious grief were not

Were fashioned from the fox's brush tomato's heel were given (Boyle 1931, 1-2)

The next section introduces the on-going drama of decomposition and decay which is the real subject of the poem:

No cradle where to rock the head

The worms came through and riddled it

The snails strung slime birds carried off what plumes of it

To garnish rump No spinet left [...] (Boyle 1931, 8-11)

\section{italicized block of prose unrolling in a series of incongruous metaphors succeeding at} breakneck speed:

The history itself began in a queer enough fashion, commenced "dear Lydia" written in the first of the book, and as if this in itself were not enough there was more for your money-a photograph allowing no mistake with a feather curled over her shoulder. "Dear Lydia" you could say it in a hundred ways to the sight of her and she moved not an eye nor caught a breath in her bosom. The book lay open there with Lydia on it whenever we stepped across the room for a look at the scorpion, and he himself swimming idly about in the glass where he survivedsomeone at birth had set a face on him, an expression in the fair middle of him, such that he wore or seemed a tall silk hat which was the rest of him as he idly rose or struck the bottom. And for what did the woman keep him if not for her neck when she was feeling hasty. There would he be so obliging as to draw off her anger. A leech, said Scathewell. A scorpion, I could not call it less than. [...] (Boyle 1931, 10-11) participates in a variety of roles, sliding, exchanging and doubling in interchangeable positions of subject, object, and observer. The result is a fantastic interplay between the rational and the subconscious evoking subtle affinities with the elegant prose of René Crevel's novel Babylone, which Boyle had translated for Black Sun Press.

Though the poem registers Boyle's commitment to the formal and stylistic breakthrough of the revolution of the word, yet one feels obliged to acknowledge that it falls short of the ideal of reestablishing a bond between man and the universe set by 
Anonymous. The vision it conveys stands for a sense of a present that is an isolated and radicalized piece of time, being at once engrossed with its individual creative consciousness and severed from the creative consciousness of the world. In this regard, "Landscape" only seems to recapitulate a paean to avant-gardist exceptionalism. However, closer attention to the context of its original production invites a more nuanced interpretation.

In reality, "A Landscape for Wyn Henderson" was not intended to be read in traditional book format, but as a piece of optical poetry run on a "reading machine" that was devised by Boyle's friend Robert Carlton Brown with a view to renovating the cultural practice of reading. One of the signatories of the transition's manifesto, Brown responded to its injunctions by designing a reading device made of a ribbon on which entire books could be printed, and which the reader could activate at variable speeds. The device drew on photographic composition, the modern cinematic qualities of the new "talkies", linear single-line ticker-tape news report, telegraphic communications, and the moving electric advertising signs. As Brown explained in transition, the objective was to "revitalize interest in the optical art of writing":

Literary language is Optical, speaking language Vocal, and the gap between them must spread till it becomes a gulf. My reading machine will serve as a wedge. Makers of words will be born; fresh, vital eye-words will wink out of dull, dismal drooling type of startled smug readers. [...] The Revolution of the Word will be won. [...] Let's have a new reading medium in time with our day, so that industrious delvers in the Word-Pile may be rapidly read and quickly understood by their own generation at least. (Brown 1930, 210)

Boyle and Lowenfels were among the poets Brown invited to contribute to the "readie anthology" he published in 1931 under his own imprint, Roving Eye Press, based in Cagnes-sur-Mer. Lowenfels sent him the elegy to Apollinaire which had also appeared in Cunard's Second Hours Press series the year before. As for Boyle's "readie", "Landscape to Wyn Henderson", it complied "to the letter" to Brown's suggestions that the contributors to his anthology dispose of "useless" words such as prepositions, conjunctions, articles and prefixes, that they use present and progressive tenses, and that they resort to the hyphen to replace punctuation, chop long words and simulate motion. As a result, the original manuscript of the poem presented a strikingly different version from the one that was later printed in traditional paged codex form:

Were made were not for lament for sore melodious grief were not - - were fashioned from the fox's brush tomato's heel were given - - should footfall step on mountainside would to come to grief by tortuous way - - were made for fertile valleys - - so high and perilous grows despair were not for you-but wind as tasty as a seaman's cheek would stay you hand - - and turn your thought to other - - - - - - no cradle where to rock the head the worms came through and riddled it - - the snails strung lime birds carried off - - what plumes of it to garnish rump - - no spinet left the flax to iron - remains the Cave the Rock the Tree - - were not for you the avalanche but Cave turned mad with fire - I saw the snails curl up like lead I saw the worms expire - - - - - (Boyle 2020, 37)

41 While this reproduction can only approximate the effect Boyle intended her "readie" to have on the reader, it appears quite clearly that the poem was meant to make a visual statement as well as an emotional one. Quite paradoxically, the "machinic" quality of the text de-emphasizes the "exceptionality" of the poem by enhancing continuity over rupture and disjointedness. Moreover, the form of experimental writing associated with the "readie" re-emphasizes the materiality of the text and, thus, facilitates a form 
of access to the world via the body that Williams (another contributor to Brown's anthology) describes as "direct contact, from the sense to the object (within us) so that what we can disclose is peeled, acute, virulent..." (Williams 1942, 23). In this sense, one understands more clearly the appeal of Brown's "reading machine" for such poets such as Boyle and Lowenfels who were engaged in the quest for a new poetic practice of anonymous impersonality that might help fuse art with life praxis. Though Brown's invention remained "exceptional" in the context of his time-inasmuch as it probably came too early and was never commercialized-yet it partook of a democratic impulse that spoke to their beliefs in the social function of art. Besides, it gave them the opportunity to breathe, quite literally, a ghost in the machine and extend their poetic search into the realm of the sensible. Last but not least, the collective and transient nature of Brown's project was also congenial to the form of transnational networked exchanges and circulation that enabled the modernist avant-garde to retain its oppositional edge.

From this perspective, Boyle's letter to Lowenfels, dated August 15 1930, is worth quoting at length; for it voices both her interest in and mixed feelings about the Anonymous project. Casting a critical glance at modern Americanized (i.e. deindividualized) society, she first chooses to read anonymity as "American," which, she says ironically, can only bode well for the reception of the Anonymous project in Europe:

I have been thinking about anonymous, and I have been thinking that it ought to be a success. Particularly because it is an entirely and completely American conception of things, and destined surely to rifle any foreign mind. [...] America and its business-like religion and its Wall Street architecture has submerged the individual so completely ... that Americans have no necessity to be individuals or to be anything, but apt. [...]

Hence anonymity. Hence the concern with being anonymous because few Americans have felt the necessity of being anything else. (Boyle 2015, 172-73)

She goes on assigning anonymity to a form of hypocrisy and conformity, making American artists blind to their own right to individuality and exceptionality: "Hence the false humility of most Americans, particularly the artist because he has been and is out of place as an individual" (173). The central paragraph of the letter further states her belief that literary anonymity should be first and foremost the matter of active experiment and lucid dedication, and not an excuse for idle talk among literary circles and coteries:

The IDEA as an idea is unassailable. But as a scheme discussed in the London Times it is inconsistent and unnecessary. Particularly unnecessary if you are weary and gutted with the literature of today, then avoid the literary attitude and write things that nobody hears about at all, except the people you love. The thing is that neither you nor I can ever live, except through some miracle, and our earnings from our writing. WE CAN'T. Let's be good poets and let it go at that. (Boyle 2015, 173) conditions of modernist literary production quoted in the introduction of this article, they also emphasize the idea that, for the many among the younger generation of American artists, to forge the uncreated conscience of their own exceptionalism was inevitable and of vital necessity.

In this respect, while Anonymous will probably remain a by-line in the history of literary modernism, it allows us to read and understand modernist experiences of cultural exceptionality in a new light. I would also contend that it invites reflection on 
commitment to possible cultural action in today's world where reconciliation between "the inner and the outer, the concrete and the abstract, the face in the dream and the face at the breakfast table" (Anonymous 9) is, more than ever, a matter of individual and collective importance and urgency.

\section{BIBLIOGRAPHY}

Anderson, Sherwood. “A Man's Mind.” The New Republic 63 (21 May 1930): 22-23.

Anonymous. The Need for Anonymity. Paris: Carrefour Editions, n.d.

Apollinaire, Guillaume. “Zone.” In Alcools, poèmes, 1989-1913. Paris: Mercure de France, 1913. 7-15

Boyle, Kay. "Letter to Walter Lowenfels August 15 1930.” In Kay Boyle. A Twentieth-Century Life in Letters. Ed. Sandra Spanier. Urbana Chicago and Springfield: University of Illinois Press, 2015. 172-175.

---. “A Landscape for Wyn Henderson.” In A Glad Day. New York: New Directions, 1938. 10-13.

---. “A Landscape for Wyn Henderson." In Readies for Bob Brown's Machine. A Fac-Simile Edition. Ed. Craig J. Spaer and Eric B. White. Edinburgh: Edinburgh UP, 2020. 39-41.

Brown, Robert Carlton. “Experiment.” transition 19-20 (June 1930): 208-210.

---. Readies for Bob Brown's Machine. Cagnes-sur-Mer: Roving Eye Press, 1931.

Canby, Henry Seidel. “Anon is Dead.” American Mercury 8 (May 1926): 79-84.

Cowan, James C. "Elegies for Lawrence." In The Spirit of D. H. Lawrence: Centenary Studies. Ed. Gamini Salgādo et al. London, Basingstoke: McMillan Press, 1988. 311-326.

Eliot, T.S. Selected Essays. London, Faber and Faber, 1972.

Ferry, Anne. “'Anonymity': The Literary History of a Word.” New Literary History 33:2 Anonymity (Spring 2002): 193-214.

Ford, Hugh. Published in Paris. American and British Writers, Printers, and Publishers in Paris, 1920-1939. Yonkers, NY: The Pushcart Press, 1975.

Forster, E. M. “Anonymity. An Enquiry.” The Calendar of Modern Letters 2:9 (November 1925): 145-56; The Atlantic Monthly (November 1925): 588-95.

Fraenkel, Michael. Young Werther's Brother. Paris: Carrefour Editions, 1930.

---. The Otherness of D. H. Lawrence. 1939. With an afterword by Karl Orend. Paris, London: Editions Carrefour Alyscamps, 2000.

Griffin, Robert T. “Anonymity and Authorship.” New Literary History 30:4 Case Studies (Autumn 1999): 877-95.

Harris, Michael. The Henry Miller-Michael Fraenkel Correspondence, Hamlet. Paris: M. P. Harris \& Carrefour Alyscamps, 1997.

Hazlitt, Henry. "The Cult of Anonymity." Nation 131 (1 Oct. 1930): 350. 
Jackson, Dennis. “The World Press Reports D. H. Lawrence's Death.” D. H. Lawrence Review 14:1 (Spring 1981): 33-72.

Jaffe, Aaron. Modernism and the Culture of Celebrity. Cambridge: Cambridge UP, 2005.

Lawrence, D. H. Studies in Classic American Literature. 1923. Cambridge: Cambridge UP, 2003.

---. “Review, Nation, 1926." William Carlos Williams: The Critical Heritage. Ed. Charles Doyle. New York and London: Routledge, 1997. 89-92.

---. “The Theatre.” In Twilight in Italy and Other Essays. Cambridge: Cambridge UP, 2002. 133-53.

Lowenfels, Walter. Apollinaire: An Elegy. Paris: Hours Press, 1930.

---. USA with Music: An Operatic Tragedy. Paris: Carrefour Editions, 1930.

---. Elegy in the Manner of a Requiem in Memory of D. H. Lawrence. Paris: Carrefour Editions, 1932.

Miller, Henry. "Unpublished Letter by Henry Miller to Alfred Perlès. Paris (November 12 1935): np." In The Henry Miller-Michael Fraenkel Correspondence, Hamlet. Ed. Michael Harris. Paris: M. P. Harris \& Carrefour Alyscamps, 1997.

---. “Creative Death.” Purpose 10:2 (April-June 1938): 67-76.

--- and Michael Fraenkel. Hamlet. Paris, Carrefour, II volumes, 1939 and 1941.

---. “The Apocalyptic Lawrence.” Southern Review 312:3 (Summer 1946): 254-56.

---. The Henry Miller Reader. Edited with an introduction by Lawrence Durrell. New York: New Directions, 1959.

Nesme, Axel. L'autre sans visage. Lecture de l'élégie américaine. Paris: Honoré Champion, 2012.

Nin, Anaïs. D. H. Lawrence: An Unprofessional Study. Paris, Titus, 1932.

Orend, Karl et al (eds.). A Short History of Carrefour Press and Archive. Paris, London: Editions Carrefour Alyscamps, 1994.

"Proclamation." transition, 16-17 (June 1929): 13.

Ramazani, Jahan. "Nationalism, Transnationalism and the Poetry of Mourning." In The Oxford Handbook of Elegies. Ed. Karen Weisman. Oxford: Oxford UP, 2010. 601-619.

Richards, I. A. Practical Criticism. A Study of Literary Judgment. London: Kegan Paul, 1929.

Robson, Mark. “The Ethics of Anonymity.” The Modern Language Review 103:2 (Apr., 2008): 350-63. Saturday Review of Literature. "D. H. Lawrence." 6 (15 March 1930): 817.

Tucker, Herbert, F. “Introduction.” New Literary History 33:2, Anonymity (Spring 2002): iv.

Williams, Carlos William. In the American Grain. New York, NY: New Directions, 1925.

---. “An Elegy for D. H. Lawrence: Died 2 March 1930.” Poetry: a Magazine of Verse 45 (March 1935): 311-15.

---. “Advice to the Young Poet.” View II:3 (October 1942): 23.

Witemeyer, Hugh (ed.). Pound/Williams: Selected Letters of Ezra Pound and William Carlos Williams. New York: New Directions, 1996. 


\section{NOTES}

1. Hugh Ford's Published in Paris and Karl Orend and Constance Merril's A Short History of Carrefour Press and Editions contain brief but accurate accounts of Carrefour Editions and the Anonymous movement.

2. Three Essays in Weather Counterpoint was meant to comprise Lowenfels's "Mental Climate," Fraenkel's "The Weather Paper," and Miller's "The Universe of Death" (later published in Phoenix I:1 (1938): 33-64).

3. Alfred Perlès dropped out of the exchange soon after it started. The Hamlet correspondence was translated in French and published by Correa in 1956, in Le Chemin de la Vie, a collection directed by Maurice Nadeau.

4. In his afterword to Fraenkel's The Otherness of D. H. Lawrence, Karl Orend notes that Miller's The World of Lawrence was not published until 1980 by Capra Press, in Santa Barbara. The book contains "The Universe of Death" which was originally part of a tripartite book with Lowenfels and Fraenkel, Three Essays in Weather Counterpart.

5. Lowenfels' first collection of poetry, Episodes \& Epistles, was published in 1925 by Thomas Seltzer in New York. After he relocated to Paris, Lowenfels' poems were accepted for publication in Ernest Walsh's expatriate literary journal This Quarter and in Eugene Jolas' transition, as well as in periodicals in London.

6. Apollinaire. An Elegy was printed in a limited run of 150 signed copies on Canson-Montgolfier paper set in 16pt Calson Old Face, with a cover designed by Yves Tanguy.

7. Canby's unsigned obituary notice was published on the front page of the March $15^{\text {th }}$ Saturday Review of Literature.

8. On this subject, see Jahan Ramazani's article. Axel Nesme's monograph on the American elegy also contains an enlightening analysis of Williams' poem as a construct of hybrid voices.

9. James Cowan notes that Lowenfels' elegy "consisted, according to the author, 'of lines 4678 to 5184 from book II of REALITY PRIME.' Intended for a choral service, in the manner of a Requiem for a dead man, the poem is marked with marginal abbreviations for voices: B, Baritone, $C$, Chorus, Q, Choir, T, Tenor, S, Soprano, A, Contralto, O, Bass" (Cowan 312).

10. Nin published the first literary study of Lawrence's work, D. H. Lawrence: An Unprofessional Study. Paris, Titus, 1932. Her analysis focused on Lawrence's characters' struggle "to achieve complete life and a sincere understanding of the gods in the center of our bodies" (19). In particular, she was interested in the way Lawrence had touched with what she calls "the woman within the builder-artist. Woman pure and simple-or neither pure nor simple." Nin encouraged Miller to read Lawrence, which he did in the spring of 1931, and their correspondence shows the evolution of Miller's response to Lawrence under the influence of Nin.

\section{ABSTRACTS}

The article examines the relatively little-known "Anonymous" project launched in Paris by Michael Fraenkel and Walter Lowenfels in 1930 with a view to advancing our understanding of modernist "exceptionalism" as a heterogeneous and malleable cultural construct. It first aims to reassess the project's political and aesthetic stance by contextualizing it in the contemporary social and artistic debate over anonymity-including its entanglements with discussions of impersonality within and across modernist circles. It takes a close look at poems written by 
contributors to Anonymous to demonstrate how their authors claimed, disclaimed or reclaimed authorship as a way to reassert cultural and social authority within the culture of the market place. The article further investigates the connection of these experiments with the late 1920s technomodernist "revolution of the word," so as to emphasize the challenge these writers faced as they tried to avoid the pitfalls of cultural exceptionality.

Cet article a pour objet le projet "Anonymous ", lancé à Paris par Michael Fraenkel et Walter Lowenfels en 1930, qui donne à comprendre "l'exceptionnalisme" moderniste comme une construction culturelle hétérogène et malléable. Il s'attache d'abord à resituer les objectifs esthétiques et politiques poursuivis par Anonymous dans le contexte du débat social et artistique des années vingt sur l'anonymat, en soulignant notamment les liens complexes qu'ils entretiennent avec la question de l'impersonnalité. En prenant appui sur une sélection de poèmes directement issus d'Anonymous, il analyse ensuite le lien entre anonymat littéraire et autorité culturelle et sociale, au sein du marché culturel de l'époque. Enfin, il examine la relation qu'entretiennent ces expérimentations poétiques avec la «révolution du mot» technomoderniste de la fin des années vingt, afin de mieux comprendre les stratégies mises en œuvre par leurs auteurs pour éviter le piège de l'exceptionnalisme culturel.

\section{INDEX}

Mots-clés: Anonymous, modernisme, entre-deux-guerres, échanges transatlantiques, impersonnalité, poésie, mort créative, New Criticism

Keywords: Anonymous, modernism, interwar, transatlantic exchanges, impersonality, poetry, creative death, New Criticism

\section{AUTHORS}

\section{ANNE REYNES-DELOBEL}

Maîtresse de conférences HDR

Université d'Aix-Marseille

anne.reynes@univ-amu.fr 